\title{
PROJECT BASED LEARNING IMPLEMENTATION TO STUDENT'S SCIENTIFIC ATTITUDE AND CREATIVITY IMPROVEMENT
}

\author{
Aep Saepudin \\ Prodi Gizi, FIKes, Universitas Islam Al-Ihya Kuningan \\ Jln. Mayasih no 11 Kelurahan Cigugur Kuningan Jawa Barat 45552, Indonesia \\ aepsaepudin8466@yahoo.co.id
}

Doi: https://doi.org/10.31943/mangiferaedu.v5i1.89

Received: April 4, $2020 \quad$ Accepted: July 28, 2020 Published: July 31, 2020

Citation: Saepudin, A (2020). Project Based Learning Implementation to student's Scientific

Attitude and Creativity Improvement. Jurnal Mangifera Edu, 5(1), 64-77.

\begin{abstract}
Scientific attitude and creativity of students in processing information when the learning process is still low. The purpose of this study is 1) to obtain data on the implementation of project based learning model learning can improve scientific attitudes, 2) to determine the implementation of project based learning model learning can increase student creativity. The method used in this research is the experimental method with the technique of sampling by cluster random sampling. The research instrument used was the task and rubric of students' scientific attitudes and creativity. Data analysis techniques normality, homogeneity and hypothesis. The hypothesis $t=4.476$ means that the implementation of the project based learning model of learning can improve scientific attitudes. The hypothesis $t=8.486$ means that the project based learning model of learning can increase student creativity. The conclusion is the implementation of the project based learning model of learning can improve students' scientific attitudes and creativity. Teachers should apply a project based learning model with video media on waste recycling materials.
\end{abstract}

Keywords: Project based learning model, scientific attitude, creativiy

\section{ABSTRAK}

Sikap ilmiah dan kreativitas siswa dalam mengolah informasi saat proses pembelajaran masih rendah. Penelitian ini bertujuan untuk memperoleh data implementasi model pembelajaran project based learning terhadap peningkatan sikap ilmiah dan mengetahui implementasi model pembelajaran project based learning terhadap peningkatan kreativitas siswa. Penelitian ini berupa penelitian eksperimen dengan teknik pengambilan sampel yaitu cluster random sampling. Instrument penelitian yang digunakan adalah task dan rubric sikap ilmiah siswa dan kreativitas. Teknik analisis data yang digunakan adalah uji normalitas, uji homogenitas dan uji hipotesis. Hasil uji hipotesis menunjukkan nilai $t=4,476$ dengan Sig. 0,001 0,05 artinya implementasi model pembelajaran project based learning berpengaruh terhadap peningkatan sikap ilmiah. Hasil uji hipotesis menunjukkan nilai $t=8,486$ dengan Sig. 0,001 <0,05 artinya implementasi model pembelajaran project based learning berpengaruh terhadap peningkatan kreativitas siswa. Disimpulkan bahwa implementasi model pembelajaran project based learning dapat meningkatkan sikap ilmiah dan kreativitas siswa. Model pembelajaran Project Based Learning dapat digunakan dalam pembelajaran khususnya materi daur ulang sampah.

Kata Kunci: Model project based learning, sikap ilmiah, kreativitas. 


\section{PENDAHULUAN}

Hakikat IPA salah satunya Biologi yaitu kumpulan konsep dan prinsip, proses memperoleh eksplanasi ilmiah dan konteks dalam kehidupan sehari-hari. Pada pembelajaran sains tidak hanya sekedar pengetahuan yang bersifat ilmiah namun memiliki dimensidimensi ilmiah penting diantaranya, content of science, science proses skils, dan karakteristik dan watak sikap limiah (Stiggins, 1994). Oleh karena itu pembelajaran Biologi sebaiknya dilaksanakan dengan memperhatikan produk, proses, dan sikap ilmiah siswa. Sikap ilmiah melandasi proses ilmiah yang kemudian menghasilkan produk. Begitu sebaliknya, produk dapat mendorong terjadinya proses ilmiah yang baru dan akan menumbuhkan sikap ilmiah yang memiliki komponen proses ilmiah seperti: mengamati, mengklasifikasi, memprediksi, merancang dan melaksanakan eksperimen. Dan sikap ilmiah siswa dapat terdeskripsikan degan melihat kejujuran, terbuka, tanggung jawab, bekerja sama, berpikir kritis, rasa ingin tahu, disiplin, objektif, peduli terhadap lingkungan (Insyasiska, 2015). Sejalan terbentunya sikap ilmah siswa akan memunculkan kreatifitas siswa sebagi hasil belajar sehingga tujuan dari pembelajaran biologi tercapai (Utami, 2015). Tuntutan kurikulum saat ini mengharapkan siswa memiliki kecakapan kognitif, kemampuan dalam dunia nyata, dan berakhlak mulia serta lebih aktif dalam proses pembelajaran.Tetapi, pembelajaran Biologi di sekolah saat ini masih terpaku pada paradigma penelusuran informasi dan masih belum menrapkan penilaian ada aspek sikap ilmiah dan kretaifitas siswa dalam pembelajaran Biologi.

Berdasarkan hasil survey pendahuluan dan wawancara dengan guru Biologi SMA Negeri 1 Cigugur sikap ilmiah siswa masih rendah, hal ini ditunjukkan dengan masih rendahnya rasa ingin tahu terhadap konsep yang diajarkan, kurang peduli terhadap lingkungan sekitar sebagai aplikasi ilmu pengetahuan dan menjadi faktor penyebab masih rendahnya sikap ilmiah siswa. Hal ini didukung data task dan rubrik pada saat proses pembelajaran dengan memperoleh nilai rata-rata 2,20 dari indikator sikap ilmiah. Dan pembelajaran yang mengarah pada belajar mandiri agar siswa dapat mengkonstruk pengetahuannnya masih sangat kurang, dilihat dari hasil observasi yaitu siswa kurang fokus dan termotivasi untuk memahami materi pelajaran, siswa kurang berani mengemukakan pendapat/ide atau gagasan, kurang percaya diri dan mandiri dalam menggali pengetahuan, dan tidak mencoba hal-hal yang baru dalam memecahkan masalah pembelajaran. Hal ini didukung data task dan rubrik pada saat proses pembelajaran dengan memperoleh memperoleh nilai rata-rata 2,20 dari indikator kreativitas siswa (wawancara dan observasi guru Biologi SMAN 1 Cigugur). 
Pembelajaran Biologi diharapkan mengarah pada pembelajar yang lebih ideal dengan permasalahan yang real dan berorientasi pada siswa sehingga siswa dapat mengkonstruksi sendiri pengetahuannya dan terlibat aktif dalam mencari informasi. Namun, rendahnya sikap ilmiah dan kreativitas siswa diantaranya disebabkan kurang tepatnya guru Biologi menerapkan model pembelajaran. Oleh karena itu, penelitian ini mencoba menerapkan model pembelajaran project based learning. Model pembelajaran project based learning melibatkan siswa dalam masing-masing kelompok melaksanakan proyek dengan melakukan investigasi atau penyelidikan berdasarkan pengalaman yang dimiliki. Kemudian diadakan diskusi kelompok. Dalam kegiatan tersebut guru sebagai fasilitator yang memfasilitasi siswa dalam melakukan proyek dampai mendapatkan produk (Antika, 2017).

Project based learning pada penelitian ini dengan menggunakan media video pemanfaatan sampah menjadi produk daur ulang yang bermanfaat pada konsep daur ulang sampah karena siswa aktif dalam mengumpulkan data dan fakta tentang cara menanggulangi sampah, memecahkan masalah sampah organik dan anorganik, dan berusaha merencanakan atau merancang produk untuk mengatasi masalah sampah tersebut dengan produk daur ulang sampah. Produk yang dihasilkan dalam pembelajaran daur ulang sampah adalah taplak meja yang terbuat dari bungkus kopi bekas dengan direkam untuk dijadikan video cara pembuatannya. Produk taplak meja dapat menjadi salah atu alternatif pemecahan masalah (fleksibilitas) tentang sampah rumah tangga, gagasan baru yang dihasilkan oleh kreativitas siswa, dan produk originalitas atau yang menambahkan atau memperinci detail-detail dari suatu objek, gagasan atau situasi sehingga menjadi lebih menarik.

Hal ini sejalan dengan Insyasiska (2015) yang menunjukkan berdasarkan uji lanjut LSD menunjukkan bahwa project based learning dapat mempengaruhi motivasi belajar siswa lebih tinggi 14\%, kreativitas siswa meningkat 31,1\%, kemampuan berpikir kritis meningkat $34 \%$ dan kemampuan kognitif siswa juga meningkat 28,9\% dari pada pembelajaran yang diberikan tanpa melalui proyek. Pembelajaran berbasis proyek memotivasi siswa untuk belajar mandiri menemukan informasi sendiri dari berbagai sumber, seperti tim ahli, lingkungan sekitar, media dan internet. Siswa termotivasi bekerjasama dengan tim untuk menghasilkan ide-ide kreatif yang kemudian diwujudkan dalam suatu produk. Pembelajaran proyek ini juga melatih agar siswa berpikir kritis terhadap permasalahan kontekstual yang berkaitan dengan materi biologi melalui tema-tema yang mereka pilih, sehingga dapat meningkatkan kemampuan kognitif siswa mulai dari menganalisis, mensintesis, mengevaluasi, dan mencipta. 
Penerapan model pembelajaran project based learning dengan penggunaan modul laboratorium kuis yang diberikan sebelum dan sesudah siswa mengikuti lab. Aktivitas menunjukkan keuntungan postlab yang signifikan dalam pemahaman mereka tentang jalur sekretori dan teknik demonstrasi yang digunakan untuk menilai persepsi siswa tentang keampuhan kegiatan laboratorium. Hasil survei ini menunjukkan bahwa eksperimen berhasil memenuhi seperangkat tujuan pendidikan yang didefinisikan oleh instruktur (Kang et al., 2013). Project based learning dapat meningkatkan kemampuan siswa dalam keterampilan proses sains terutama kemampuan mengamati dan kemampuan mengklasifikasi. Sikap siswa tentang sifat sains, kepercayaan tentang belajar, dan kepercayaan pada kemampuan mereka untuk membaca, menganalisis, dan menjelaskan artikel penelitian. Kemampuan analitis siswa dan pemahaman ilmuwan sebagai manusia, namun juga dapat mempengaruhi secara positif. Kepercayaan siswa dengan analisis literatur primer, wawasan mereka terhadap proses sains dan keyakinan mereka tentang belajar (Hoskins, et al., 2011).

Penelitian ini bertujuan untuk memperoleh data implementasi model pembelajaran project based learning terhadap peningkatan sikap ilmiah pada konsep daur ulang sampah dan untuk mengetahui implementasi model pembelajaran project based learning dapat meningkatkan kreativitas siswa pada konsep daur ulang sampah di SMA Negeri 1 Cigugur Kabupaten Kuningan

\section{METODOLOGI PENELITIAN}

Penelitian ini menggunakan desain quasy eksperimen dengan pre-post test control group. Penelitian ini dilakukan di SMA N 1 Cigugur dengan populasi sebanyak 252 siswa. Teknik pengambilan sampel yang digunakan dalam penelitian ini adalah simple random sampling kemudian didapat 2 kelas yang masing masing berjumlah 34 siswa untuk kelas eksperimen dan 34 siswa untuk kelas kontrol dengan kriteria menentukan kedua kelas tersebut adalah kemampuan intelegensi siswa bersifat heterogen, mengalami pemasalahan dalam perolehan hasil belajar siswa yang berada di bawah KKM.

Instrumen yang digunakan untuk mengukur sikap ilmiah adalah task and rubric untuk mengetahui sikap ilmiah yang meliputi sikap jujur, terbuka, tanggung jawab, objektif, bekerjasama, berpikir kritis, rasa ingin tahu, disiplin, peduli lingkungan. Kreativitas siswa dengan indikator 1) Kemampuan elaborasi (menghasilkan banyak gagasan baru), 2) Kemampuan flexibilitas (membuat berbagai alternatif pemecahan masalah), 3) Kemampuan originalitas (menambahkan atau memperinci detail-detail dari suatu objek, gagasan atau situasi sehingga menjadi lebih menarik).Instrumen yang digunakan adalah task dan aspek 
penilaian untuk mengetahui kreativitas yang meliputi (1) elaborasi, 2) flexibilitas, dan 3) originalitas.

Adapun tahapan yang dilakukan dalam penelitian ini yaitu 1). Tahap persiapan meliputi semua hal untuk pelaksanaan uji coba instrumen, 2). Tahap pelaksanaan ini dilakukanlah pretest, perlakuan, dan posttest untuk kelas kontrol dan kelas eksperimen, 3) Tahap pengolahan data, dan analisis data yaitu untuk mengetahui apakah data berdistribusi normal atau tidak menggunakan uji normalitas dengan teknik kolmogorov-smirnov dilakukan sebagai prasyarat analisis. Setelah data memiliki distribusi normal, dilakukan uji homogenitas dan dilakukan uji t jika data homogen untuk menarik kesimpulan. Dan Mannwhitney test dilakukan apabila diketahui data tidak normal.

\section{HASIL DAN PEMBAHASAN}

\section{Implementasi Model Pembelajaran Project Based Learning dapat Meningkatkan Sikap Ilmiah}

Hasil penelitian sikap ilmiah siswa yang menggunakan instrumen task and rubric skala holistik dengan skor maksimal tiga kategori kompeten, diperoleh perbedaan sikap ilmiah siswa antara kelas kontrol dengan mode pembelajaran diskusi dan kelas eksperimen dengan pembelajaran Project Based Learning pada materi daur ulang limbah di SMA Negeri 1 Cigugur Kabupaten Kuningan, yang disajikan dalam Gambar 1.

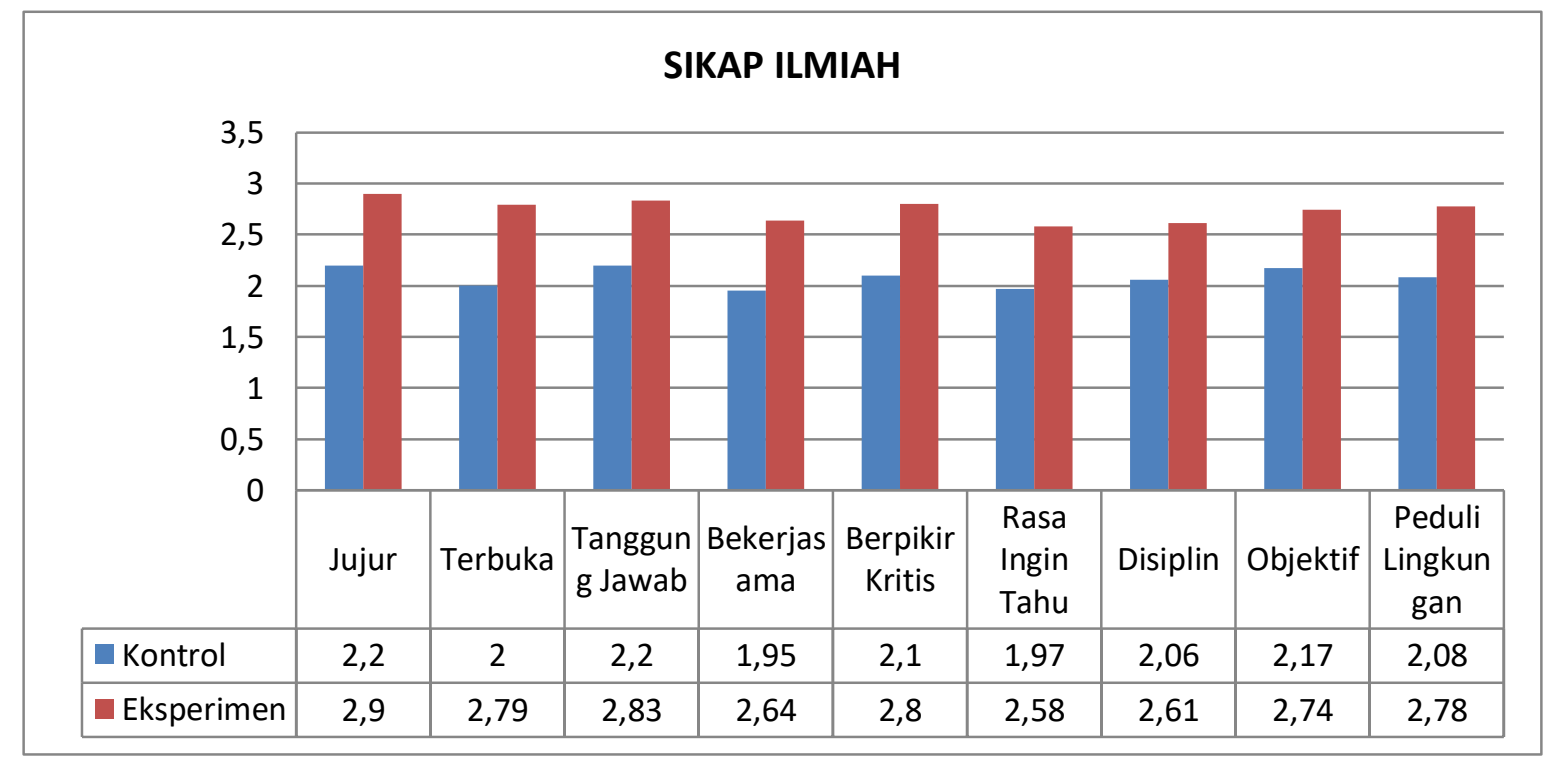

\section{Gambar1. Rekapitulasi Sikap Ilmiah Siswa Kelompok Kontrol dan Kelompok Eksperimen}

Berdasarkan hasil pengolahan dan analisis perbedaan sikap ilmiah siswa diuraikan sebagai berikut : 1) Sikap jujur di kelas eksperimen memperoleh nilai rata-rata 2,90 lebih baik dibanding di kelas kontrol memperoleh nilai rata-rata 2,20,2) Sikap terbuka di kelas 
eksperimen memperoleh nilai rata-rata 2,79 lebih baik dibanding di kelas kontrol memperoleh nilai rata-rata 2,0,3) Sikap tanggung jawab di kelas eksperimen memperoleh nilai rata-rata 2,83 lebih baik dibanding di kelas kontrol memperoleh nilai rata-rata 2,20.4). Sikap bekerjasama di kelas eksperimen memperoleh nilai rata-rata 2,64 lebih baik dibanding di kelas kontrol memperoleh nilai rata-rata 1,95. 5) Sikap berpikir kritis di kelas eksperimen memperoleh nilai rata-rata 2,80 lebih baik dibanding di kelas kontrol memperoleh nilai ratarata $1,93,6)$ Sikap rasa ingin tahu di kelas eksperimen dengan model pembelajaran project based learning memperoleh nilai rata-rata 2,58 lebih baik dibanding di kelas kontrol dengan penerapan model diskusi kelompok yang memperoleh nilai rata-rata 1,97, 7) Sikap disiplin di kelas eksperimen dengan model pembelajaran project based learning memperoleh nilai rata-rata 2,61 lebih baik dibanding di kelas kontrol dengan penerapan model diskusi kelompok yang memperoleh nilai rata-rata 2,06,8). Sikap objektif di kelas eksperimen memperoleh nilai rata-rata 2,74 lebih baik dibanding di kelas kontrol dengan penerapan model diskusi kelompok yang memperoleh nilai rata-rata 2,17,9) Sikap peduli lingkungan di kelas eksperimen memperoleh nilai rata-rata 2,78 lebih baik dibanding di kelas kontrol yang memperoleh nilai rata-rata 2,08.

Berdasarkan diagram di atas, sikap jujur lebih tinggi di atas kemampuan yang lain, hal ini karena model pembelajaran project based learning memfasilitas siswa di kelas eksperimen berusaha terlibat secara aktif melaksanakan/mengerjakan semua tugas yang diberikan tanpa mencontek pekerjaan orang lain, melaporkan data pengamatan sesuai dengan hasil percobaan. Hasil penelitian di atas sesuai dengan teori yang dikemukakan oleh Sunarto (2010) model pembelajaran Project Based Learning mempunyai beberapa karakteristik, yaitu (1) mengembangkan pertanyaan atau masalah, yang berarti pembelajaran harus mengembangkan pengetahuan yang dimiliki oleh siswa, (2) memiliki hubungan dengan dunia nyata, berarti bahwa pembelajaran yang outentik dan siswa dihadapkan dengan masalah yang ada pada dunia nyata, (3) menekankan pada tanggung jawab siswa, merupakan proses siswa untuk mengakses informasi untuk menemukan solusi yang sedang dihadapi, (4) Penilaian, penilaian dilakukan selama proses pembelajaran berlangsung dan hasil proyek yang dikerjakan siswa.

Sejalan dengan Garcia-Mila \& Andersen (2007) menunjukkan bahwa penyelidikan memfasilitasi siswa dalam berpikir metakognitif. Hal ini sejalan dengan hasil penelitian yang dilakukan oleh peneliti. Karena dengan kesadaran metakognitif dapat meningkatkan kemandirian siswa dalam melaksanakan sikap ilmiah contohnya siswa memiliki kemampuan dalam indikator yang tinggi dalam mengamati dan mengklasifikasi. Karena kesadaran 
metakognitif menekankan keterlibatan siswa dalam merencanakan penyelidikan dan pengamatan di lapangan untuk mengumpulkan data, memonitoring atau melakukan pengawasan tentang pencemaran lingkungan yang terjadi di lingkungan sekolah, serta melakukan evaluasi atau feedback berkaitan dengan cara mencegah dan upaya mengatasi pencemaran lingkungan yang terjadi di lingkungan sekitar.

Penerapan metode diskusi dan kerjama dalam pembelajaran dapat meningkatkan aktivitas belajar siswa sehingga siswa lebih mudah dalam memahami materi pelajaran, karena menurut Jean Piaget, dasar dari belajar adalah aktivitas anak bila ia berinteraksi dengan lingkungan sosial dan lingkungan fisiknya. Pertumbuhan anak merupakan suatu proses sosial. Anak tidak berinteraksi dengan lingkungan fisiknya sebagai suatu individu terikat, tetapi sebagai bagian dari kelompok sosial. Akibatnya lingkungan sosialnya berada diantara anak dengan lingkungan fisiknya. Interaksi anak dengan orang lain memainkan peranan penting dalam mengembangkan pandangannya terhadap alam. Melalui pertukaran ide-ide dengan orang lain, seorang anak yang tadinya memiliki pandangan subyektif terhadap sesuatu yang diamatinya akan berubah pandangannya menjadi obyektif. Aktivitas mental anak terorganisasi dalam suatu struktur kegiatan mental yang disebut "skema" atau pola tingkah laku (Sanjaya, 2010).

Berdasarkan hasil analisis uji hipotesis menunjukkan nilai Sig. sebesar 0,608 > 0,05, dengan nilai $\mathrm{t}=4,476$ dengan Sig. 0,001 $<0,05$ artinya implementasi model pembelajaran project based learning dapat meningkatkan sikap ilmiah pada konsep daur ulang sampah di SMA Negeri 1 Cigugur Kabupaten Kuningan. Sejalan dengan Quillin and Thomas, 2015 menunjukkan bahwa gmbaran representasi visual penting bagi pelajar dan ilmuwan, seperti menggambar model untuk mengaktifkan penalaran berbasis model visual. Namun sedikit instruktur biologi yang mengenalinya. Menggambar sebagai keterampilan proses sains yang dapat diajarkan, yang tercermin dari ketidakhadirannya dalam. Visi dan perubahan, kompetensi inti pemodelan dan simulasi laporan. Selanjutnya, penelitian difusi pada gambar bias Sulit untuk mengakses, mensintesis, dan menerapkannya pada praktik kelas. Yang kondusif bagi siswa menggambar secara umum dan penalaran berbasis model visual pada khususnya. Intervensi yang disarankan disusun untuk mengatasi unsur-unsur yang mempengaruhi, melek visual. Penalaran berbasis model visual, dengan contoh spesifik yang dikutip untuk masing-masing.

Didukung pula oleh Kothari (1966) bahwa untuk mengidentifikasi potensi sikap ilmiah siswa dibutuhkan lingkungan pembelajaran yang dapat menggali potensi ilmiah siswa. Oleh karena itu sikap ilmiah siswa kelas eksperimen lebih baik dibandingkan kelas 
kontrol, sehingga implementasimodel pembelajaran project based learningdapat meningkatkansikap ilmiah siswa.

\section{Implementasi Model Pembelajaran Project Based Learning dapat Meningkatkan Kreativitas Siswa}

Berdasarkan hasil penelitian dengan menggunakan analisis task dan rubrik perbedaan kreativitas siswa, dan analisis pengolahan nilai rata-rata pretest kelompok kontrol memperoleh nilai rata-rata 61,55 sedangkan pretest kelompok eksperimen memperoleh nilai rata-rata 58,80. Hal ini membuktikan bahwa kreativitas siswa pada materi daur ulang sampah baik di kelompok kontrol maupun di kelompok eksperimen tidak berbeda secara signifikan, diuraikan sebagai berikut :

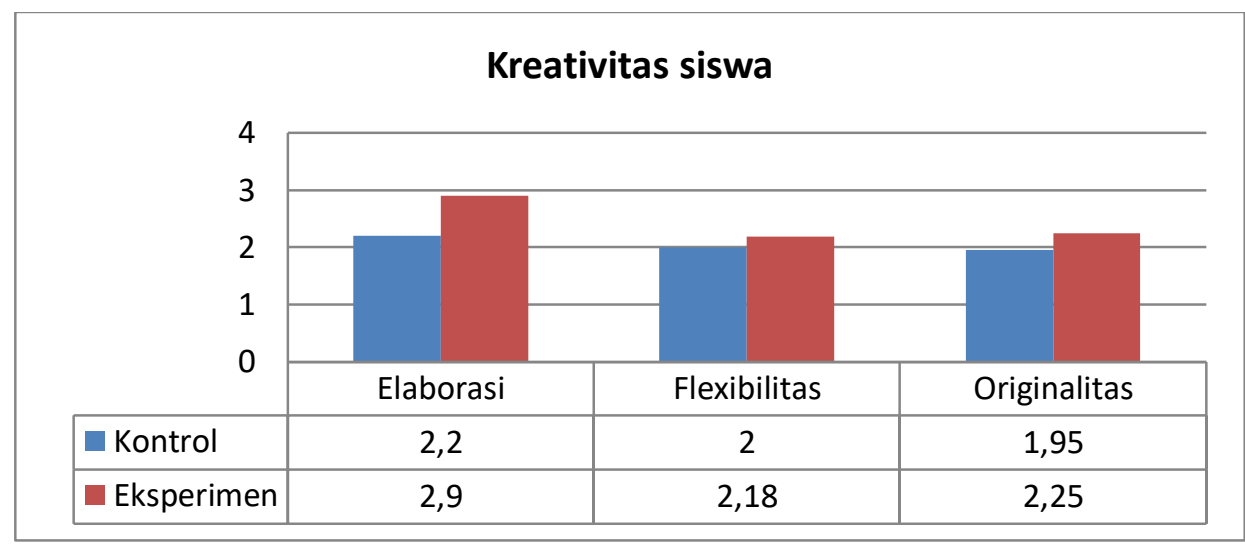

Gambar 2. Rekapitulasi Kreativitas Siswa Kelompok Kontrol dan Kelompok Eksperimen

Berdasarkan gambar rekapitulasi kreativitas siswa diperoleh yaitu, 1) Kemampuan elaborasi (menghasilkan banyak gagasan baru) di kelas eksperimen memperoleh nilai ratarata 2,90 lebih baik dibanding di kelas kontrol memperoleh nilai rata-rata 2,20. Hal ini dibuktikan dengan siswa di kelas eksperimen berusaha mengemukakan pendapat/ide/gagasan, mengemukakan gagasan dalam upaya menanggulangi sampah serta menghasilkan gagasan atau produk untuk mengatasi sampah dengan proses daur ulang sampah serta merancang produk daur ulang sampah dengan memperhatikan segi kebermanfaatan, produk yang dihasilkan adalah taplak meja dari bungkus kopi yang memiliki kebermanfaatan untuk digunakan di atas meja sehingga lebih menarik. Sedangkan kelompok kontrol hanya mengorientasi masalah sampah, mendiskusikan dan menyelesaikan lembar tugas, memanfaatkan buku paket untuk menyelesaikan lembar tugas sehingga tidak mengalami secara langsung.

Hal ini didukung hasil penelitian Wahida et al. (2015), menunjukkan bahwa penerapan project based learning dapat meningkatkan berpikir kreatif siswa, 2) Kemampuan flexibilitas 
(membuat berbagai alternatif pemecahan masalah) di kelas eksperimen memperoleh nilai rata-rata 2,18 lebih baik dibanding di kelas kontrol memperoleh nilai rata-rata 2,0. Hal ini dibuktikan dengan kelas eksperimen siswa aktif mendiskusikan dan menyelesaikan tugas belajar, mengemukakan berbagai alternatif atau berbagai solusi untuk memecahkan masalah sampah di lingkungan serta memilih alternatif solusi yang baik untuk mengatasi permasalahan sampah di lingkungan baik melalui tindakan preventif atau pencegahan, maupun kuratif melalui tindakan secara nyata di lapangan, produk berupa taplak meja memiliki nilai jual (value) sehingga siswa yang memiliki kreativitas tinggi dapat memperoleh uang tambahan dari produk taplak meja. Sedangkan kelompok kontrol hanya mendiskusikan lembar tugas berkaitan dengan klasifikasi jenis-jenis sampahberdasarkan tempat, dan bahan pencemar dengan memanfaatkan buku sumber, siswa bertukar pendapat berkaitan dengan klasifikasi jenis pencemaran. Hal ini didukung hasil penelitian Antika dan Nawawi menunjukan bahwa peningkatan keterampilan berpikir kreatif kelas ekperimen dan kelas kontrol berbeda signifikan yang ditunjukan oleh hasil uji t $\mathrm{N}$-gain $(0,004<0,05)$ dengan rata-rata lebih tinggi dibandingkan kelas kontrol. Analisis per-indikator menunjukan peningkatan (N-gain) kelas eksperimen pada indikator Flexibility dan Originality berkriteria tinggi, dan pada indikator Elaboration berkriteria rendah. Hasil tersebut didukung dengan aktifitas belajar mahasiswa kelas eksperimen lebih tinggi dibanding kelas kontrol, selain itu angket tanggapan siswa menunjukan hasil yang positif terhadap penerapan model Project Based Learning.

Kemampuan originalitas (menambahkan atau memperinci detail-detail dari suatu objek, gagasan atau situasi sehingga menjadi lebih menarik) di kelas eksperimen memperoleh nilai rata-rata 2,25 lebih baik dibanding di kelas kontrol memperoleh nilai ratarata 1,95. Hal ini dibuktikan dengan siswa di kelas eksperimen aktif mendiskusikan, bekerjasama, mengkomunikasikan dan mengemukakan pendapat berkaitan prediksi dari berbagai sampah dengan menganalisis jenis-jenis sampah, faktor penyebab pencemaran lingkungan serta upaya duar sampah serta mempresentasikan hasil diskusi dan penyelidikan di depan kelas, siswa aktif bertanya, menjawab pertanyaan, mengemukakan pendapat atau gagasan serta memberikan jawaban tambahan, produk berupa taplak meja memiliki estetika tinggi dalam proses pembuatan dan hasilnya sehingga orang akan tertarik untuk memilikinya. Sedangkan kelompok kontrol mempresentasikan hasil diskusi didepan kelas, kurang aktif dalam bertanya dan menjawab pertanyaan serta kurang berani dalam mengemukakan pendapat atau gagasan. 
Sejalan Quillin \& Thomas (2015) menunjukkan bahwa gambaran representasi visual penting bagi pelajar dan ilmuwan, seperti menggambar model untuk mengaktifkan penalaran berbasis model visual. Namun sedikit instruktur biologi yang mengenalinya. Menggambar sebagai keterampilan proses sains yang dapat diajarkan, yang tercermin dari ketidakhadirannya dalam. Visi dan perubahan, kompetensi inti pemodelan dan simulasi laporan. Selanjutnya, penelitian difusi pada gambar bias. Sulit untuk mengakses, mensintesis, dan menerapkannya pada praktik kelas. Yang kondusif bagi siswa menggambar secara umum dan penalaran berbasis model visual pada khususnya. Intervensi yang disarankan disusun untuk mengatasi unsur-unsur yang mempengaruhi, melek visual. Penalaran berbasis model visual, dengan contoh spesifik yang dikutip untuk masing-masing. Didukung oleh Sani (2014) model pembelajaran Project Based Learning memiliki tujuh karakteristik mengarahkan siswa untuk menginvestifigasi ide dan pertanyaan penting, merupakan proses inkuiri, terkait dengan kebutuhan dan minat siswa, berpusat pada siswa dengan membuat produk dan melakukan presentasi secara mandiri, menggunakan ketrampilan berpikir kreatif, kritis, dan mencari informasi untuk melakukan investigasi, menarik kesimpulan, dan menghasilkan produk, dan terkait dengan permasalahan dan isu dunia nyata yang autentik.

Berdasarkan hasil uji hipotesis menunjukkan nilai Sig. sebesar 0,017<0,05, dengan nilai $\mathrm{t}=-1,536$ dengan Sig. 0,129>0,05 artinya tidak terdapat perbedaan yang signifikan antara kelas kontrol dengan kelas eksperimen. Dan berdasarkan hasil analisis uji menunjukkan nilai Sig. sebesar 0,713 > 0,05, dengan nilai $\mathrm{t}=8,486$ dengan Sig. 0,001 < 0,05 artinya implementasi model pembelajaran project based learning terhadap peningkatan respon siswa pada materi daur ulang sampah di SMA Negeri 1 Cigugur Kabupaten Kuningan. Sejalan dengan Stone (2014), menyatakan bahwa penerapan model pembelajaran project based learning dengan media visual dapat meningkatkan keterlibatan siswa secara aktif dalam proses bertanya, melakukan pengamatan, melatih siswa dalam memecahkan tugas belajar, meningkatkan komunikasi dan kerjasama diantara siswa dalam kelompok belajar, mengembangkan kemampuan siswa dalam menghubungkan materi pelajaran dengan kehidupan nyata, dan meningkatkan pemahaman dan hasil belajar siswa.

Berdasarkan hasil analisis dan perhitungan nilai kemampuan berpikir kritis kelas eksperimen lebih baik dibandingkan kelas kontrol, sehingga implementasi model pembelajaran project based learning dapat meningkatkan kreativitas siswa pada konsep daur ulang sampah. Hal ini didukung oleh hasil penelitian yang dilakukan oleh Jenkinson \& McGill (2012) menunjukkan bahwa secara keseluruhan, animasi yang paling kompleks 
adalah yang paling efektif dalam membina pemahaman siswa terhadap kejadian yang digambarkan. Hasil ini menunjukkan bahwa, dipilih konteks pembelajaran, representasi yang semakin kompleks mungkin lebih diinginkan untuk disampaikan sehingga meningkatkan keterampilan mengamati dan mengklasifikasi sel. Sejalan pula dengan Madhuri \& Broussard (2008) menunjukkan bahwa salah satu tantangan instruktur terbesar adalah membuat siswa terhubung dengan subjek, dengan cara yang mendorong mereka untuk belajar. Kami mendeskripsikan perancangan visual kartun Biologi perkembangan untuk mendorong hubungan yang lebih dalam antara siswa dan lapangan Perkembangan biologi dalam pendekatan kami, kami menciptakan sebuah komunitas praktik ilmiah, difokuskan pada penyelidikan dampak lingkungan terhadap perkembangan embrio dan diinformasikan oleh media populer dan ilmiah, pertanyaan siswa sendiri, dan instrukturnya. Tujuan kami adalah untuk melibatkan siswa dengan cara yang berarti dengan materi, untuk berkembang keterampilan proses sains siswa, dan untuk meningkatkan pemahaman siswa tentang prinsip-prinsip yang luas perkembangan biologi Meskipun tantangan yang signifikan muncul saat diimplementasikan, penilaian menunjukkan menggunakan pendekatan ini untuk mengajarkan biologi perkembangan sarjana sukses. Sri (2014) menunjukkan bahwa terdapat perbedaan yang signifikan antara penguasaan konsep pada materi pencemaran lingkungan pada kelas eksperimen yang proses pembelajarannya mengimplementasikan praktikum berbasis keterampilan proses sains menggunakan LKS berbantuan multimedia dan respon siswa terhadap implementasi praktikum berbasis keterampilan proses sains menggunakan LKS berbantuan multimedia sebesar $64 \%$ artinya direspon dengan baik oleh siswa kelompok eksperimen.

Hal ini didukung oleh hasil penelitian yang dilakukan oleh Kang et al. (2013), menunjukkan bahwa penerapan model pembelajaran project based learning dengan penggunaan modul laboratorium kuis yang diberikan sebelum dan sesudah siswa mengikuti lab. Aktivitas menunjukkan keuntungan postlab yang signifikan dalam pemahaman mereka tentang jalur sekretori dan teknik demonstrasi yang digunakan untuk menilai persepsi siswa tentang keampuhan kegiatan laboratorium. Hasil survei ini menunjukkan bahwa eksperimen berhasil memenuhi seperangkat tujuan pendidikan yang didefinisikan oleh instruktur. Senada dengan pendapat Hoskins et al. (2011), menyatakan bahwa penerapan model pembelajaran project based learning dapat meningkatkan kemampuan siswa dalam keterampilan proses sains terutama kemampuan mengamati dan kemampuan mengklasifikasi. Sikap siswa tentang sifat sains, kepercayaan tentang belajar, dan kepercayaan pada kemampuan mereka untuk membaca, menganalisis, dan menjelaskan 
artikel penelitian. Kemampuan analitis siswa dan pemahaman ilmuwan sebagai manusia, namun juga dapat mempengaruhi secara positif. Kepercayaan siswa dengan analisis literatur primer, wawasan mereka terhadap proses sains dan keyakinan mereka tentang belajar.

Begitu juga dari hasil analisis observasi atau pengamatan aktivitas belajar siswa termasuk kategori baik dimana siswa aktif melakukan pengamatan atau mencatat dan serta menganalisis data serta berusasha membuat produk sebagai alternatif pemecahan masalah di lingkungan sekitar. Dan dari hasil tes essay diperoleh nilai rata-rata 85,29 yang telah memenuhi indikator kemampuan berpikir kreatif. Hasil penelitian ini sesuai dengan teori Muliawati (2010), mengemukakan bahwa model pembelajaran project based learning dapat melatih belajar mandiri siswa dalam mencari dan menggali informasi atau pengetahuan dari berbagai sumber belajar, mengembangkan kemampuan memecahkan masalah pembelajaran, meningkatkan kemampuan untuk mengumpulkan dan menganalisis data dan fakta yang relevan, dapat memotivasi pelajar dengan melibatkannya di dalam pembelajarannya, membiarkan sesuai minatnya, menjawab pertanyaan dan untuk membuat keputusan dalam proses belajar, meningkatkan kerjasama diantara siswa dalam mendiskusikan lembar kerja siswa, meningkatkan aktivitas dan kreativitas siswa dalam memperoleh pengetahuan dan informasi, dan mengembangkan kemampuan berpikir kreatif. Sejalan dengan Nur'aeni (2011), menunjukkan bahwa terdapat pengaruh yang signifikan model pembelajaran Project Based Learning terhadap kemampuan berpikir kreatif siswa dan pemahaman konsep siswa sehingga hasil yang diperoleh lebih baik, pemahaman konsep siswa pada konsep pencemaran tidak ditentukan dengan adanya berpikir kreatif siswa, karena pemahaman konsep lebih menekankan kepada kebenaran suatu konsep.

Berdasarkan hasil analisis dan perhitungan nilai kreativitas kelas eksperimen lebih baik dibandingkan kelas kontrol, sehingga implementasi model pembelajaran project based learning terhadap peningkatan kreativitas siswa pada konsep daur ulang sampah. Sejalan dengan Utami (2015), menunjukkan adamodel pembelajaran PJBL berbantu Instagram terhadap kemampuan berpikir kreatif siswa kelas X SMA Negeri 8 Surakarta dengan didukung dari hasil rata-rata siswa pada kelas eksperimen $(82,72)$ lebih tinggi dibanding dengan kelas kontrol (77,12). Didukung oleh Patston et al. (2017), menyatakan bahwa untuk dapat menggali kreativitas siswa tidak hanya menggunakan pembeajaran konvensional. Sebaiknya menerapkan pembelajaran abad 21 yang menggunakan model pembelajaran inovatif salah satu nya yaitu dengan project based learning sebagai alternative.

\section{SIMPULAN}

https://jurnal.biounwir.ac.id/index.php/mangiferaedu|75 
Berdasarkan hasil penelitian dan pembahasan, penulis menarik kesimpulan adalah implementasi model pembelajaran project based learning terhadap peningkatan sikap ilmiah pada konsep daur ulang sampah dan implementasi model pembelajaran project based learning dapat meningkatkan kreativitas siswa pada konsep daur ulang sampah di SMA Negeri 1 Cigugur Kabupaten Kuningan. Saran dalam penelitian ini adalah guru biologi seyogyanya menerapkan model pembelajaran project based learning dengan media video pada materi daur ulang sampah penerapan model pembelajaran project based learning dapat meningkatkan sikap ilmiah dan kreativitas siswa dalam melakukan merancang proyek, membuat jadwal, melaksanakan kegiatan proyek dan merancang produk yang dihasilkan.

\section{DAFTAR PUSTAKA}

Antika, R. N., \& Nawawi, S. (2017). Pengaruh Model Project Based Learning pada Mata Kuliah Seminar Terhadap Keterampilan Berpikir Kreatif Mahasiswa. Jurnal Pendidikan Biologi Indonesia, 3(1), 72-79.

Hoskins, S. G., Lopatto, D., \& Stevens, L. M. (2011). The CREATE Approach to primary Literature Shifts Undergraduates' Self-Assessed Ability to Read and Analyze Journal Articles, Attitudes About Science, and epistemological Beliefs. CBE_Life Sciences Education, 10(4), 368-378.

Insyasiska, D., Zubaidah, S., \& Susilo, H. (2017). Pengaruh Project Based Learning Terhadap Motivasi Belajar, Kreativitas, Kemampuan Berpikir Kritis, dan Kemampuan Kognitif Siswa pada Pembelajaran Biologi. Jurnal Pendidikan Biologi, $7(1), 9-21$.

Jenkinson, J., \& McGill, G. (2012). Visualizing Protein Interactions and Dynamics: Evolving a Visual Language for Molecular Animation. CBE-Life Sciences Education, 11(1), 103-110.

Jennifer, K., Hood-DeGrenier. (2012). Undergraduate Cell Biology Laboratory a Western Blot-Based Investigation of the Yeast Secretory Pathway Designed for an Intermediate-Level. CBE-Life Sciences Education. Vol. 7, 107-117

Kang, P. J., Hood-DeGrenier, J. K., \& Park, H.-O. (2013). Coupling of Septins to the Axial Landmark by Bud4 in Budding Yeast. Journal of Cell Science, 126(5), 1218-1226.

Kothari, D.S. (1966). Report of the Education Commission 19641-1966. New Delhi: Govt. of India.

Madhuri, M., \& Broussard, C. (2008). Do I Need to Know This for the Exam? Using Popular Media, Inquiry-Based Laboratories, and a Community of Scientific Practice to Motivate Students to Learn Developmental Biology. CBE-Life Sciences Education, 7(1), 36-44. 
Jurnal Mangifera Edu, Volume 5, Nomor 1, Juli 2020, 64-77

Garcia-Mila, M., \& Andersen, C. (2007). Developmental Change in Notetaking During Scientific Inquiry. International Journal of Science Education, 29(8), 1035-1058.

Muliawati. (2014). Model Pembelajaran Aktif, Kreatif dan Inovatif. Surabaya: Kartika.

Nur'aeni, Sri. (2011). Model Pembelajaran Inkuiri terhadap Kemampuan Berpikir Kreatif dan Pemahaman Konsep Pencemaran Lingkungan (Studi pada Siswa kelas VII di SMP Negeri 2 Maleber. Thesis. Kuningan. Universitas Kuningan.

Patston, T. J., Cropley, D. H., Marrone, R. L., \& Kaufman, J. C. (2017). Teacher SelfConcepts of Creativity: Meeting the Challenges of the 21st Century Classroom. The International Journal of Creativity \& Problem Solving, 27(2), 23-34.

Quillin, K., \& Thomas, S. (2015). Drawing-to-Learn: A Framework for Using Drawings to Promote Model-Based Reasoning in Biology. CBE_Life Sciences Education, 14(1), es2.

Sani. (2014). Model-model Pembelajaran. Jakarta: Bumi Aksara.

Sanjaya, Wina. (2010). Strategi Pembelajaran (Berorientasi Standar Proses Pendidikan). Jakarta: Kencana Prenada Media Group.

Sri, Eva Nur. (2014). Implementasi Praktikum Berbesis Keterampilan Proses Sains Menggunakan LKS Berbantu Multimedia terhadap Peningkatan Penguasaan Konsep dan Sikap Ilmiah pada Konsep Pencemaran Lingkungan. Thesis. Kuningan. Universitas Kuningan.

Stiggins, R. J. (1994). Student-Centered Classroom Assessment. Merrill New York.

Stone, E. M. (2014). Guiding Students to Develop an Understanding of Scientific Inquiry: a Science Skills Approach to Instruction and Assessment. CBE-Life Sciences Education, 13(1), 90-101.

Sunarto. (2010). Strategi Pembelajaran. Jakarta: Bumi Aksara.

Utami, R. P., Probosari, R. M., \& Fatmawati, U. M. I. (2015). Pengaruh Model Pembelajaran Project Based Learning Berbantu Instagram Terhadap Kemampuan Berpikir Kreatif Siswa Kelas X SMA Negeri 8 Surakarta. Bio-Pedagogi, 4(1), 47-52.

Wahida, F. (2015). Pengaruh Model Pembelajaran Berbasis Proyek terhadap Keterampilan Berpikir Kreatif dan Hasil Belajar Siswa Kelas X SMA Negeri 1 Parigi. JSTT, 4(3). 